\title{
Vocation of Humanity in Genesis 2-3 and its Implications for Eco-Theology in Africa
}

\author{
Luke Emehielechukwu Ijezie
}

\section{ABSTRACT}

\begin{abstract}
This essay recognizes the fact that human beings are created for a purpose, and this is referred to as the human vocation. The essay examines how the text of Genesis 2-3 presents this vocation and its ecological dimensions with implications for eco-theology in Africa. The aim is to provide a theological contribution to the contemporary ecological problems with particular reference to the African continent. Contemporary Africa is faced with a myriad of problems emanating from the way people treat the environment. The essay argues that eco-theology can provide a contextual theological framework for confronting the ecological challenges of the African continent. The methodology is both descriptive and analytical, and it employs the results of the historical critical method of biblical exegesis.
\end{abstract}

Keywords: ecology, ecosystem, human vocation, labour
Published Online: March 31, 2021

ISSN: $2736-5514$

DOI : 10.24018/ejtheology.2021.1.2.10

Luke Emehielechukwu Ijezie

Catholic Institute of West Africa, Port Harcourt, Nigeria.

(e-mail: emehiele@yahoo.com)

Corresponding Author

\section{INTRODUCTION}

This essay examines the famous story of Adam and Eve in Genesis 2-3 from the perspective of its ecological implications. The aim is to present a biblical basis for confronting the myriads of contemporary ecological problems with particular reference to the Africa of today. As a matter of fact, the universe is a place of interconnected things and human life is lived in a climate of interconnected relationships. When such relationships are not properly managed, one experiences a state of brokenness. It is this state of brokenness that is currently menacing all cadres of relationship in the contemporary world. There is brokenness on the level of inter-human relationships. There is brokenness on the level of interspecies relationship. There is brokenness within the natural environment and, more, on the level of the relationship between human beings and the entire cosmos.

This has resulted in the ever increasing ecological crisis of the present age. It is for this reason that the theme of ecology has become a global concern. The discussion has been carried to all sectors of human endeavour, and no branch of human knowledge is excluded.

In response to this, theologians, including African theologians, have long taken up the challenge of providing a way forward through what is technically called ecotheology ${ }^{1}$. The term eco-theology expresses a way of doing theology that takes into consideration the environmental or

${ }^{1}$ See, for instance, the collection of articles in J. N. K. Mugambi and Mika Vähäkanges (eds), Christian Theology and Environmental Responsibility (Nairobi: Action Publishers, 2001); J. T. I. Osunkwo, God and the Human Environment: Catholic Principles of Environmental Stewardship as a Template for Action in Nigeria (Bloomington, IN: iUniverse, 2015); L. E. ecological issues confronting the world. Such a theology can be contextual, global or cosmopolitan, as the case may be. The fact is that many environmental challenges confront the contemporary world that theological and religious discourses can no longer be business as usual. It is noteworthy that most official documents of the Church now contain sections on the environment. The most recent example is the Papal Encyclical of Pope Francis, Laudato Si: On Care of the Common Home. There was also the Post-Synodal Apostolic Exhortation, Africae Munus, of Pope Benedict XVI on the Church in Africa, where the Holy Father makes this significant statement on the respect of creation and the ecosystem:

Some business men and women, governments and financial groups are involved in programmes of exploitation which pollute the environment and cause unprecedented desertification. Serious damage is done to nature, to the forests, to flora and fauna, and countless species risk extinction. All of this threatens the entire ecosystem and consequently the survival of humanity. I call on upon the Church in Africa to encourage political leaders to protect such fundamental goods as land and water for the human life of present and future generations and for peace between peoples ${ }^{2}$.

The Pope's emphasis on the respect for creation and the ecosystem is really very significant. More significant is the fact that he summons the Church in Africa to carry out the

Ijezie, S. Audu, A. I. Acha (eds), Theology and Ecological Issues (Port Harcourt: CATHAN Publication, 2017)

${ }^{2}$ Pope Benedict XVI, Post-Synodal Apostolic Exhortation, Africae Munus, 80 . 
mission of championing the ecological campaign. This essay becomes a theological response to the call. It also rhymes with what Pope Francis says when he says: "Theological and philosophical reflections on the situation of humanity and the world can sound tiresome and abstract, unless they are grounded in a fresh analysis of our present situation, which is in many ways unprecedented in the history of humanity ${ }^{3}$."

The present essay argues that eco-theology can provide a contextual theological framework for confronting the ecological challenges of the African continent. Contemporary Africa is faced with a myriad of problems emanating from the way people treat the environment. The menace of diseases, the spate of hunger and malnourishment, the conflict ravaging many groups, the menace of desert encroachment and flooding in many parts of Africa trace their origins to the abuse or lack of proper care of the inhabited environment.

\section{HUMAN VOCATION IN GENESIS 2-3}

The text of Genesis 2-3 narrates in a graphic form the creation and fall of humanity, identified as Adam and Eve. The text pays particular attention to the garden as the context of the primary human vocation on earth. The term "human vocation" is used here in the sense of the original role or occupation given to humanity by God at creation which can be regarded as the "call" of humanity. The creation of Adam was dictated by the need to have a custodian for the garden, and the expulsion from the garden comes about as a result of the human abuse of this role, which is an abuse of the laws of the garden. In this light one can treat the text as a locus technicus for the discussion of the ecological implications of the human vocation in creation. As a matter of fact, the text has been read from diverse perspectives and been used for diverse doctrinal and pedagogical purposes. The present approach to the text recognizes the fact that the same biblical material can lend itself to diverse interpretations in diverse contexts and with diverse considerations. This attests to the dynamic and ever creative nature of the divine word.

\section{A. The Nature of the Text}

The text's limits are actually $2: 4 b-3: 24$, and it is conventionally regarded as the second account of creation, thus distinguishing it from the first account of creation in 1:12:4a. The two creation accounts in Genesis 1-3 need not be read as chronological records of the origin of the world, even though many readers still see them on that literal, historical level. However, critical scholarship has long exposed the fact of the literary and imaginative nature of the accounts ${ }^{4}$. Many elements within the text itself point in many directions, calling the attention of the reader to search for deeper meanings. M. Vervenne puts it well when he considers the book of Genesis as "a marvellous literary work of human imagination which Ancient Israelite society created in order

\footnotetext{
${ }^{3}$ Pope Francis, Laudato Si. On the Care of the Common Home, no. 17.

${ }^{4}$ See the recent studies in: A. Wénin, ed., Studies in the Book of Genesis. Literature, Redaction and History (BETL 95; Leuven: Univ. Press, 2001); James Alfred Loader, "The Primeval Narrative as a Literary Myth," OTE 16 (2003) 309-321.

${ }^{5}$ M. Vervenne, "Genesis 1,1-2,4. The Compositional Texture of the Priestly Overture to the Pentateuch," in Studies in the Book of Genesis. Literature, Redaction and History, 35.

${ }^{6}$ See the articulation of this majority opinion in Richard J. Clifford, "The Hebrew Scriptures and the Theology of Creation," Theological Studies 46 (1985) 507-553; Vervenne, "Genesis 1,1-2,4," 35-79; M. Bauks, "Genesis 1 als Programmschrift der Priesterschrift [Pg]," in Studies in the Book of Genesis, 333-345.
}

to develop an understanding of the 'condition humaine' and its foundations in the divine realm in particular ${ }^{5}$." According to most scholars, that the opening account of creation in Genesis (1:1-2:4a) belongs to the Priestly writer or the Priestly school, as the case may be ${ }^{6}$. According to R. Clifford, the account in Gen 1:1-2:4 was composed as a preface to the whole book of Genesis, and more especially the primeval history in Gen 2:4b-11:267. What this implies is that the account of the creation, involving the fall of Adam and Eve in 2:4b-3:24, antedates the account in 1:1-2:4a.

\section{B. Structure of the Text}

In the light of the argument of this essay, the text's structure will be presented along the lines of the vicissitudes of the human vocation within the garden. The text is structured in a schema of crisis-resolution.

2:4-5: Crisis Situation: earth without vegetation and human labour

2:6-25: First Resolution: the planting of a garden and creation of the Adam for labour

3:1-21: Complication of the situation: human abuse of the garden

3:22-24: Final Resolution: expulsion from labour in the garden to labour on the dry ground

The narrative begins with the inauguration of the human vocation of labour in the garden and ends with the expulsion of human beings from labouring in the garden to labouring on the dry ground ('ădāmāh). The story can thus be read with the human vocation of labour as a guiding motif.

\section{Analysis of the Text}

1) Crisis Situation: Earth without Vegetation and Human Labour (2:4-5)

This introductory part of the text $(2: 4 b-5)$ points out the problem faced by the created cosmos. This problem is what is meant in this essay as the crisis situation.

At the time when YHWH God made earth and heaven, there was as yet no wild bush on the earth nor had any wild plant yet sprung up, for YHWH God had not sent rain on the recognize, and there was no man ('ādām) to till the soil (Gen 2:4b-5).

The crisis is that there is no vegetation in the land (v. 5). This is an unwholesome state of affairs, as the situation resembles that of a desert, an ironic contrast with the first account of creation in Genesis 1 where the crisis was that of managing the immense waters that covered the land. For the present text, the world in a state of no vegetation cannot realize its purpose and, so, it is a world in crisis. The text mentions two reasons for the present crisis (v. 5b): first, there is yet no moisture in the land, and second, there is no human being (Adam) to work on the dry ground ('ădāmāh). The narrator in this way exposes his understanding of the special

${ }^{7}$ Clifford, "The Hebrew Scriptures," 520. While many scholars agree on the P origin of Gen 1:1-2:4a and some other P texts in Genesis, there has been much debate on the origin of the other Genesis accounts. Since the mid 1980 s there has been a serious rethinking on the identity of what used to be called the Yahwistic (J) and Elohistic (E) Sources. The current state of scholarship is that only very few still argue on the existence of these two sources. Much more emphasis has been laid on the Priestly and Deuteronomic/Deuteronomistic Sources with the other materials being attributed to unidentified and miscellaneous sources both antedating and postdating the two major sources. For critical review and bibliography, see J. Blenkinsopp, The Pentateuch. An Introduction to the First Five Books of the Bible (New York: Doubleday, 1990) 1-97, 229-242; E. Nicholson, The Pentateuch in the Twentieth Century (Oxford: 1998) 196-221. 
role of the human being as one who works the land, as one who takes care of the created world. The human vocation is intrinsically linked to the proper health of the land. This is linguistically expressed in the pun on the Hebrew name 'ādām. The Adam (human being) is taken from 'ădāmāh (soil). As Carol A. Newsom puts it, "to call the creature 'ādām is to recognize its solidarity with Earth $^{8}$." It is the need to put the land in proper condition that calls for the presence of the human being. So the challenge is that of developing the dry land. How does the Creator resolve this crisis?

2) First Resolution: the Planting of a Garden and Creation of the Adam for Labour (2:6-25)

The text presents the situation of a dry land or desert that needs to be transformed. In the first account of creation, the problem was that of the immense waters of the deep covering the earth surface. Now, in this other account, it is the problem of dryness and lifelessness. Three elements can be identified in the resolution of the present crisis. These are water, human labour and the garden. The water functions to make the land arable for cultivation. Water is a symbol of life, and a world without water is a lifeless world. But water is not enough to make the created land realize its divine purpose. There must be a human agency to manage affairs. The author of this text is very careful to underline the fact that the watering of the earth is not done by man but by the Creator himself. God brings the water, fashions the man and plants the garden himself. Here God is presented as the great Agriculturist.

The garden is planted in a place called Eden (2:8). According to scholarly discussions, the word "Eden" is either derived from the Akkadian noun edinu (probable loan-word from Sumerian eden) meaning "plain, steppe", or from the Aramaic root ' $\mathrm{dn}$, which is a common West Semitic root, meaning "abundance, delight, luxury"9. Many traditional and modern interpretations adopt the second option, which is the Aramaic origin. A related Hebrew verb 'dn (Neh 9:25) means "to delight, luxuriate" 10 . It is, therefore, most likely that the name Eden is given to the very place the garden is located just to express the fact that it is a fertile and luxuriant place, a scene of agricultural abundance, given its watery nature. This may explain why the LXX translates gan-'ēden (garden of Eden) in Gen 3:23,24 as ho paradeisos tēs truphēs ("the garden of luxuries") ${ }^{11}$. The popular term "paradise" is actually a loan-word from Old Persian (pardēsu) used in the LXX to render the word "garden" (Hebrew gan) ${ }^{12}$.

All that the human being is entrusted to do in the garden is to till or work the garden and to watch over it. The two functions here are represented in Gen 2:15 by the verbs 'ābad (to work, till) and shāmar (to watch): "YHWH God took the man and settled him in the garden of Eden to till ('ābad) it and to watch over (shāmar) it." The Hebrew verb "ābad is used in this context in the sense of "tilling" or "working"13. Another sense of the word is "to cultivate", and this opens it up, in one way or the other, to the ideas of cultural development and cultic service (cultus). It is not strange that

\footnotetext{
${ }^{8}$ Carol A. Newsom, "Common Ground: An Ecological Reading of Genesis 2-3," in The Earth Story in Genesis (eds. Norman C. Habel \& Shirley Wurst; The Earth Bible 2; Sheffield: Sheffield Academic Press, 2000) 63.

${ }^{9}$ See F. C. Fensham, JNSL 15 (1989) 89; I. Cornelius, NIDOTTE 3, 331; H. N. Wallace, "Eden, Garden of," Anchor Bible Dictionary 2, 281.

${ }^{10}$ Cornelius, NIDOTTE 3, 329-330, 331.

${ }^{11}$ Wallace, "Eden, Garden of," ABD 2, 281

${ }^{12}$ B. Jacobs-Hornig, "gan," TDOT 3, 34-36

${ }^{13}$ Eugene Carpenter, "“bd”, NIDOTTE 2, 304.

${ }^{14}$ G. Sauer, "shmr", TLOT 3,
}

the Hebrew word for servant ("ebed) has the same root as the word for tilling ('ābad). The cultivation or tilling of the garden is a work of service. The neighbouring word shāmar, meaning "to watch, keep" connotes the idea of protection and maintenance of a good ${ }^{14}$. According to Victor P. Hamilton, the garden is not merely something to be possessed but something to be protected ${ }^{15}$. Man's role is, thus, to cultivate the garden and act as a guard or protector over it. One way to understand this is to see it as an expression of a call to service, for as Gerhard von Rad says, "That man was transferred to the garden to guard it indicates that he was called to a state of service and has to prove himself in a realm that was not his own possession." 16 In other words, the human being is put in the garden as God's own servant.

The servant role of man in the garden underlies the fact that the garden of Eden is not really that traditional fantasy of a place for full enjoyment without work. As Hamilton puts it, "Work enters the picture before sin does, and if man had never sinned he still would be working. Eden certainly is not a paradise in which man passes his time in idyllic and uninterrupted bliss with absolutely no demands on his daily schedule."17 This fantastic picture of life in the garden was also rife among some early Rabbinic schools, as the Talmud attests: "When Adam was in the garden of Eden [and sinless], he used to recline while the ministering angels roasted flesh and filtered wine for him" (Sanh 59b $)^{18}$. In the Genesis text, however, work or labour is presented as a divine mandate through which the human being is called to develop the created world.

The responsibility of cultivating and protecting the garden is so onerous that the man (Adam) needs a helper. So God makes the woman to act as a "helper" ('ēzer) to man. The woman comes not just to break man's loneliness but to ease man's burden in the work of service in the garden. It is good to underline this point because often the idea of helper has been so ideologically treated that this original intention appears to get little attention ${ }^{19}$. The animals by their nature could not partner with the man. The woman is created to help in the work of service in the garden and, thus, to share in the vocation of the man. The future of life in the garden would now depend on the complementariness, solidarity and cooperative work of the two. On the basis of this text, one can say that the future of humanity very much depends on how both man and woman respond to their common vocation of caring for the cosmic environment which is here represented by the garden.

3) Complication of the Situation: Humanity's Abuse of the Garden (3:1-21)

The vocation of humanity as care-taker of the garden gets complicated in 3:1-7 as the man and the woman abuse the garden by eating the forbidden fruit. This abuse emanates from their inordinate desire to be like God, knowing good and evil. The consequence is a state of brokenness and instability. It is not enough to share in the divine knowledge of good and

\footnotetext{
${ }^{15}$ V. P. Hamilton, The Book of Genesis Chapters 1-17 (NICOT; Grand Rapids: Eerdmans, 1990) 171

${ }^{16}$ G. von Rad, Genesis: A Commentary, Revised Edition (London: SCM Press 1972) 80.

${ }^{17}$ Hamilton, The Book of Genesis, 171.

18 Abraham Cohen, Everyman's Talmud: The Major Teachings of the Rabbinic Sages (New York: Schocken Books, 1975) 58.

${ }^{19}$ See, for instance, the discussion in David J. A. Clines, What Does Eve Do to Help? And Other Readerly Questions to the Old Testament (JSOTS 94; Sheffield: JSOT, 1990).
} 
evil; there are many other divine qualities which they cannot attain. The human limitations or nakedness become apparent and shame follows. Human arrogance and inordinate ambition are adduced as factors in most of the contemporary ecological disasters. The author of the text is telling his hearers that the loss of the garden is as a result of human sin which brings about a disorder in the ecosystem.

The Creator God whose presence used to be a joy now becomes a dread ${ }^{20}$. This instability further plays out in the divine punishments. The serpent, earlier described as the most 'ārûm (clever) of all the animals of the field (3:1), now becomes the most 'ârûr (cursed) of the animals (3:14). The friendly relationship that seemed to exist between the serpent and the woman now gets transformed into enmity (3:15). The harmonious relationship between the woman and her husband also suffers as dominion of one over the other now sets in (v. 16) with all its disastrous consequences. The relationship between the man and the ground ('ădāmāh) gets destabilized as the land now gets cursed making man to labour more strenuously to carve out a living from the dry land (v. 17). All these and more are consequences of the abuse of the garden.

As long as the human being abuses the natural environment entrusted to his care, the ecosystem will continue to experience destabilization.

4) Final Resolution: Expulsion from Labour in the Garden to Labour on the Dry Ground (3:22-24)

The garden, which is central to the whole story, has to be protected from further abuse or desecration. The Creator himself resolves the crisis by expelling the human beings from the garden. The human vocation now changes slightly from tilling the garden to tilling the dry ground ('ădāmāh) from which the Adam was originally taken $(3: 23)$. On the other hand, the second human vocation of watching or guarding the garden is transferred to the angelic beings called the "cherubim". In this way, the story begins with labour in the garden and ends with labour on the dry ground.

The garden, which is central to the whole story, has to be protected from further abuse or desecration. The Creator himself resolves the crisis by expelling the human beings from the garden. The human vocation now changes slightly from tilling the garden to tilling the dry ground ('ădāmāh) from which the Adam was originally taken (3:23). On the other hand, the second human vocation of watching or guarding the garden is transferred to the angelic beings called the "cherubim". In this way, the story begins with labour in the garden and ends with labour on the dry ground.

\section{IMPLICATIONS FOR ECO-THEOLOGY IN AFRICA}

The text of Gen 2:4b-3:24 is, no doubt, very strategic to eco-theology as it addresses very impressively the human vocation of developing the created world. The text presents the original challenge faced by the creator as that of finding the human labour to develop the dry ground. The human being is, thus, created to till the ground and, as it were, become the care-taker of creation. This responsibility of

\footnotetext{
20 According to von Rad (Genesis, 91), "If shame was the sign more of a disturbance in man's relation to other men, then fear before God was the sign of a disorder in his relation to his Creator. Fear and shame are henceforth the incurable stigmata of the Fall in man."

${ }^{21}$ Pope Francis, Laudato Si, no. 128.

22 See Luke E. Ijezie, "God's Presence in the Created World: Its Implications for Theology and Evangelization Today," CATHAN: A
}

developing the land and caring for it challenges serious reflection on the real task of theology in the contemporary world. It calls, particularly, for a theological reorientation in contemporary Africa, where the problems of developing the dry ground still loom large. The following points can be articulated in this regard:

\section{A. Dignity of human Labour}

The text of Genesis 2-3 makes it clear that the original human vocation is to work in God's garden. This involves making the created environment a sustainable habitat for life. This underlines the dignity of human labour. As already seen, the text presents labour as being already there even before sin came, making it quite incorrect to regard labour as the consequence of sin. What the fall brings about is that humanity changes the context of labour, as the labour is shifted from the garden to the dry land $(3: 23)$. The development of the world very much depends on human labour, and this is a sacred duty. Pope Francis put it succinctly: "We were created with a vocation to work. The goal should not be that technological progress increasingly replace human work, for this would be detrimental to humanity. Work is a necessity, part of the meaning of life on this earth, a path to growth, human development and personal fulfilment." 21

What the Genesis text is saying is that genuine service of God is expressed through human labour, which is the cultivation of this world. Sometimes, there is the tendency to disregard this created world out of exaggerated religious zeal, and this often results in inauthentic living. With such mentality, many crimes against humanity and against the cosmos itself have been committed and continue to be committed. This attitude is mostly caused by the ignorance regarding the real nature of God's immanence in creation. ${ }^{22}$ It is instructive that in the Final Document of the Synod on the word of God, the Synod Fathers regard creation as "an immense page opened up before all of humanity, in which a message from the Creator can be read." 23 This is inspired by their understanding of Psalm 19, and it means that humanity can hear the voice of God by listening to creation. The very fact of listening to creation also implies listening to the culture, both traditional and modern and, in fact, taking the daily human experiences very seriously.

\section{B. Development through the Conservation of the Ecosystem}

While the human vocation is that of developing the natural world a lot depends on the mode of this development. This may be expressed in modern terminology as the development of the environment and conservation of the ecosystem. The term "ecosystem" refers to a given environment within which different species thrive in interactive relationships. It is a biological community within which different forms of life coexist and help one another. There are different types of ecosystem. A typical example is the tropical rainforest which, with its diversity of species of animal life and plant life, manifests the splendour of the natural world. Tropical rainforests are found in many parts of Africa, even though

Searchlight on Saint Paul, Proceedings of the 24th Conference of the Catholic Theological Association of Nigeria (Religio; Makurdi: Aboki Publishers, 2010) 117-135.

23 "The Word of God in the life and mission of the Church", Final Document, XIIth General Assembly of the Synod of Bishops (Vatican 25 October, 2008) no. 1. 
they are fast disappearing. According to experts, the tropical rainforests, with their rich trove of natural medicines, constitute the world's largest "pharmacy" and, particularly, the Amazon rainforests produce $40 \%$ of the world's oxygen. ${ }^{24}$ An environment without forests is an environment with limited possibilities of life and interactive relations among species. That explains why desertification and deforestation are often considered as the worst forms of ecological disaster.

In the account of Genesis 2-3, the garden comes as a remedy to a world without vegetation. Within the garden, plant life, animal life and human life develop in their biodiversity and interactive relationships. Trees with fruits of different variety develop and animals of different species team the garden. In this way, the garden serves as the effective medium to conserve the ecosystem and biodiversity. Gardens can be of different categories. Some gardens are constructed as packs for relaxation and recreation. Some are planted for vegetables and staple home crops, while some are constructed to provide for both relaxation and biodiversity. This third form falls into the category of botanical gardens. Such gardens, which are increasing all over the world today, serve to protect the species of plants that are in danger of extinction. One would have expected such gardens in many African cities, but statistics show that they are very few.

\section{Eco-Theology as a Medium for Africa's Communalistic Worldview}

The human vocation to develop and care for the earth derives its natural logic from the radical kinship between humanity and the earth. The biblical perspective is that the human being (Adam) comes from the earth ('ădāmāh) and is destined to return to the earth. The human being is, therefore, not a stranger on earth. The earth is the natural home. The care for the earth is a sine qua non for human happiness and secure existence. This radical relationship between humanity and the earth underlies these words of Thomas Berry: "We need to understand that the earth acts on all that acts upon the earth. The earth is acting in us whenever we act. In and through the earth spiritual energy is present. The spiritual energy emerges in the total complex of earth functions. Each form of life is integrated with every other life form." 25

This reflects the African communalistic and pan-cosmic approach to life which embraces not only humans but all creation. One of the constants in the African understanding of life is its relational nature. Human life is a relational phenomenon. One is living because he or she is in relationship with another. To cut off the relationship entirely is death in the traditional worldview. This is what conflict threatens to do. When such happens, community which is a relational entity is destroyed. This can happen on any level: interpersonal, family, community, religious or cosmic level. In the traditional society, the social death is officially expressed when one is ostracized from the community. In some contexts, such ostracism is likened to death sentence. This reality of the African worldview captures the attention of Pope Benedict XVI who summarizes it, thus, in an exhortatory language:

In the African worldview, life is perceived as something

\footnotetext{
${ }^{24}$ See Dokun Oyeshola, Sustainable Development. Issues and Challenges for Nigeria (Ibadan: Daily Graphics Nigeria Ltd, 2008) 16.

${ }^{25}$ T. Berry, "Spirituality of the Earth," in Charles Birch, William Eakin and Jay B. McDaniel (eds), Liberating Life: Contemporary Approaches to Ecological Theology (Maryknoll, New Yark: Orbis, 1990); reproduced in Jeff Astley, David Brown and Ann Loades, Problems in Theology: Creation. A Reader (London: T \& T Clark, 2003) 65.
}

that embraces and includes ancestors, the living and those yet to be born, the whole of creation and all beings: those that speak and those that are mute, those that think and those lacking thought. The visible and invisible universe is regarded as a living-space for human beings, but also as a space of communion where past generations invisibly flank present generations, themselves the mothers of future generations. This great openness of heart and spirit in the African tradition predisposes you, dear brothers and sisters, to hear and to receive Christ's message, to appreciate the mystery of the Church, and thus to value human life to the full, along with the conditions in which it is lived. ${ }^{26}$

A theological response to these injunctions of the Pope can more effectively be along the furtherance of eco-theology within the African continent. Eco-theology thus offers a context to articulate this highly humanistic and pan-cosmic dimension of African worldview. Such a theology will orientate nations and peoples along the part of sustainable development, which is a more responsible fulfillment of the human vocation of caring for the universe. It is this form of responsible development that contemporary Africa urgently needs.

\section{Creation Theology and the Universality of God's Family}

A theology based on creation is a theology capable of uniting all peoples and cultures. Actually, an important aspect of creation theology is the issue of the fatherhood of God which makes the whole creation one family. God is the father of creation, and in creation everything finds its home. One important implication of this is that creation is the primary locus of God's family. But one question inevitably arises here. How does one reconcile the idea of creation as God's family with the reigning understanding of the Church as the family of God?

During the First Special Assembly for Africa of the Synod of Bishops in 1994, the Synod Fathers adopted the theology of the Church as the family of God. This was the model of the Church presented to the Africans as a guide in the new era. While this theology remains stimulating, some factors today pose challenges to it: 1 . ecumenical factors - there is the question, Which Church is being talked about as the family of God? Is it the Catholic Church alone? Does the family include all Churches and all Christians? 2. Interreligious factors - Does the fact of the Church being the Family of God exclude other religions and their adherents from laying valid claims to that divine family?

The Church can validly be called God's family, but at the same time the very idea of God's family is wider than the Church, as it includes the whole creation. But, from another perspective, the very idea of Church can be widened to include the whole creation. Such understanding of the Church rhymes with the theology of the Pauline Letter to the Colossians where Christ is regarded as the fullness of

\footnotetext{
${ }^{26}$ Africae Munus, 69.
} 
creation. ${ }^{27}$ In him all things find meaning. Creation reflects the glory - presence of God, and through creation one discovers the beauty of God.

A theology based on creation as God's family has much prospects of producing an ecclesiology that can transform the modern world. Such ecclesiology will provide a viable atmosphere for dialogue at all levels and mutual understanding. The Christology underlying such ecclesiology is the biblical understanding of the Christ as the word of God. If Christ is the word of God, the Church becomes the union of all who acknowledge God's word in creation. The beauty of this theology is that it widens the understanding of Christ's presence in the world. With such understanding many systems and religious beliefs get accommodated within the new Christological framework.

\section{CONCLUSION}

The biblical text offers a very fertile ground for the promotion of ecological consciousness in the contemporary society. This is a fact that the present essay has sought to make very conspicuous. The text of Genesis 2-3 makes it clear that the protection of the environment is also God's preoccupation. It is, in fact, the primary reason for the creation of the human species. While one must acknowledge the great works human beings have made in the course of history to make the world a better place, it is also true that human recklessness has to a large extent tended to frustrate the divine plan to better the lot of creatures. The consequence has been the increase in suffering and death and devaluation of not only human life but the life of the entire creation. Africa is both a victim and a perpetrator in this ecological and human catastrophe. It becomes a challenge to theology in the continent to get more deeply involved in the current discussions in ecology. This can contribute immensely to sustainable development for the African continent.

\footnotetext{
${ }^{27}$ In Col 1:15-20, the Apostle, in an exalted poetic form, presents Christ as "the image of the unseen God, the first-born of all creation, for in him were created all things in heaven and on earth: everything visible and everything invisible, thrones, ruling forces, sovereignties, powers - all things were created through him and for him. He exists before all things and in him
}

all things hold together, and he is the Head of the Body, that is, the Church $\mathrm{He}$ is the Beginning, the first-born from the dead, so that he should be supreme in every way; because God wanted all fullness to be found in him and through him to reconcile all things to him, everything in heaven and everything on earth, by making peace through his death on the cross." 